
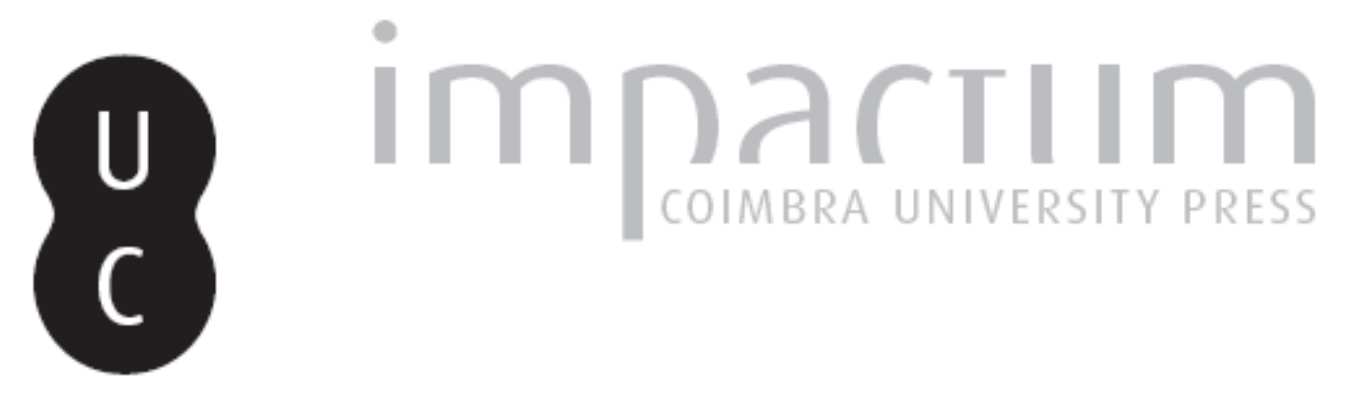

\title{
O motivo da 'guerra' na llíada e em A inaudita guerra da Avenida Gago Coutinho de Mário de Carvalho
}

Autor(es): $\quad$ Santos, Rosana Baptista dos

Publicado por: Faculdade de Letras da Universidade de Coimbra

URL persistente:

URI:http://hdl.handle.net/10316.2/32733

DOI:

DOI:http://dx.doi.org/10.14195/0870-4112_7_8

Accessed : $\quad$ 26-Apr-2023 12:20:34

A navegação consulta e descarregamento dos títulos inseridos nas Bibliotecas Digitais UC Digitalis, UC Pombalina e UC Impactum, pressupõem a aceitação plena e sem reservas dos Termos e Condições de Uso destas Bibliotecas Digitais, disponíveis em https://digitalis.uc.pt/pt-pt/termos.

Conforme exposto nos referidos Termos e Condições de Uso, o descarregamento de títulos de acesso restrito requer uma licença válida de autorização devendo o utilizador aceder ao(s) documento(s) a partir de um endereço de IP da instituição detentora da supramencionada licença.

Ao utilizador é apenas permitido o descarregamento para uso pessoal, pelo que o emprego do(s) título(s) descarregado(s) para outro fim, designadamente comercial, carece de autorização do respetivo autor ou editor da obra.

Na medida em que todas as obras da UC Digitalis se encontram protegidas pelo Código do Direito de Autor e Direitos Conexos e demais legislação aplicável, toda a cópia, parcial ou total, deste documento, nos casos em que é legalmente admitida, deverá conter ou fazer-se acompanhar por este aviso.

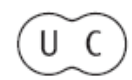




\section{Sociedade em Tumulto}

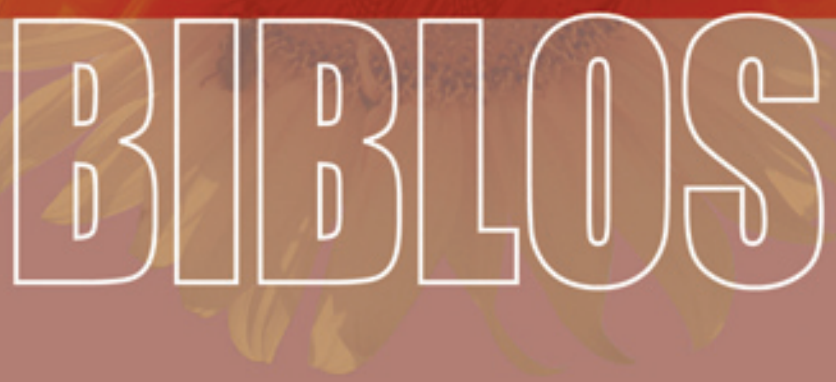

REVISTA DA FACULDADE DE LETRAS

UNIVERSIDADE DE GOIMBRA 
Biblos, n. s. VII (2009) 171-194

Rosana Baptista dos SANTos

Fundação Helena Antipoff (Minas Gerais)

\section{O MOTIVO DA 'GUERRA' NA ILIIADA E EM \\ A INAUDITA GUERRA DA AVENIDA GAGO COUTINHO \\ DE MÁRIO DE CARVALHO}

\section{Resumo}

O objetivo desse artigo é analisar a influência dos componentes épicos da guerra - sintetizados na Ilíada - no conto A inaudita guerra da Avenida Gago Coutinho, do ficcionista português Mário de Carvalho. É a essa fonte literária arcaica - bem como, num pólo distante de influência, aos relatos históricos sobre os conflitos militares nos quais Portugal se envolveu -, que o autor recorre para compor as imagens e estratagemas de guerras fantásticas, tema recorrente em sua obra.

Palavras-chave: tradição clássica grega, épica, conto, anacronismo, ficção.

\section{Abstract}

The purpose of this article is to analyze the influence of the epic components of war - summarized in the Iliad - on the tale "A inaudita guerra da Avenida Gago Coutinho," by the Portuguese fiction writer Mário de Carvalho. The author resorts to this ancient literary source, as well as to historical reports about the military conflicts in which Portugal was involved, to create images and stratagems of fantastic wars, which are a recurring theme in his work.

Keywords: Greek classical tradition, epic, short story, anachronism, fiction.

Para estabelecermos os componentes básicos que retratam uma guerra no mundo grego parece-nos ser imprescindível lançar um olhar sobre o texto homérico, visto que entendemos ter sido este, o poema sobre o conflito entre Gregos e Troianos, um texto inaugural sobre a guerra na literatura ocidental. Tal poema permitiria mais tarde uma recuperação dessa temática, isto é, a guerra, tanto no teatro clássico de Atenas como na historiografia; o que determinou uma nova 
organização desses motivos em relação ao padrão épico. ${ }^{1}$ A Ilíada,${ }^{2}$ por ser um poema que canta a guerra, tornou-se um texto básico para a compreensão das táticas bélicas utilizadas no mundo grego clássico, bem como um veículo de transmissão de valores guerreiros, encarnados em heróis de referência. Aos heróis junta-se a crença na intervenção de forças superiores sobre o destino humano, além de uma descrição detalhada das armas utilizadas em combate e do tratamento dado aos companheiros mortos em batalha, quer seja o ultraje quer o resguardo do cadáver para homenagens posteriores exigidas pelo seu mérito. A teichoscopía (ou "vista da muralha") (cf. Il. 3.166-242) e o catálogo (cf. 2.493-759) em particular, como estratégias da descrição dos exércitos, são elementos retomados na tragédia e ecoam, também, na literatura contemporânea, como veremos.

A estratégia literária a servir como introdução ao texto épico é, por tradição, o apelo à Musa e a menção do poeta, que constam do Exórdio. ${ }^{3}$

Canta, ó deusa, a cólera de Aquiles, o Pelida

(mortífera!, que tantas dores trouxe aos Aqueus

E tantas almas valentes de heróis lançou no Hades,

Ficando seus corpos como presa para cães e aves

De rapina, enquanto se cumpria a vontade de Zeus),

Desde o momento em que primeiro se desentenderam

O Atrida, soberano dos homens, e o divino Aquiles. (Il. 1.1.7)

1 Segundo Aristóteles (1448b-1449a), os poemas homéricos já continham elementos que originariam a comédia (como Magistes, poema homérico que não chegou até nós) e da tragédia (na Ilíada e Odisseia).

${ }^{2}$ Utilizamos a tradução de F. Lourenço, Homero. Ilíada (Lisboa, Livros Cotovia 2005).

${ }^{3} \mathrm{Cf}$. também as menções feitas à Musa na Odisseia $(1.1-2,8.62-64,73-76,487-$ 490, 492-498). Sobre este assunto, cf., e. g.: M. Finkelberg, 'A creative oral poet and the Muse', AJPh 111. 3 (1990) 293-303; V. Pedrick, 'The Muse corrects: the opening of the Odyssey', YClS 29 (1992) 39-62; M. W. Minton, 'Homer's invocations of the Muses: traditional patterns', TAPhA 91 (1960) 292-309. 
Sobressaidesse proêmio, segundoBrandão,na "invocaçãoà Musa", ${ }^{4}$ a proposta "de um autêntico programa narrativo". ${ }^{5}$ Para o helenista, já se percebe nitidamente um panorama da elocução global do poema, com "uma primeira pessoa, não nomeada, que se dirige a uma segunda pessoa, bem definida pelo vocativo, a deusa, para ordenar-lhe que cante a cólera de Aquiles". ${ }^{6}$ Tal projeto "narrativo" não encerra simplesmente um plano de inspiração divina, mas uma clara eleição do poeta sobre o assunto que narrará:7 "a cólera de Aquiles" (Il. 1.1) provocada pelo desentendimento com o Atrida Agamêmnon; as conseqüências dessa ira, "que tantas dores trouxe aos Aqueus" (1.2); e a interferência divina na contenda, "a vontade de Zeus" (1.5). Embora seja este o tema central do canto, não se pode ignorar a importância das peculiaridades e das "tensões inerentes ao código heróico", ${ }_{8}^{8}$ que nortearam a construção de um padrão temático retomado freqüentemente na Antigüidade Clássica e em várias outras obras posteriores.

O fato de o poeta 'ordenar' ' à deusa, e não 'pedir' que cante, afirma Brandão, poderia gerar uma certa surpresa no leitor; no entanto, para o crítico, essa seria a "representação de uma situação que, mantendo as relações necessárias com a religião puramente (como com os demais elementos da cultura), não visa a transmitir ensinamentos religiosos, mas é propriamente poética". ${ }^{10}$ Independentemente de ser uma súplica ou uma ordem dada, a verdade é que a "invocação à Musa" assinala sobremaneira um artifício poético utilizado com frequêencia no texto épico, pois a onipresença e onisciência da divindade possibilita um subterfúgio literário frente a uma provável insuficiência de dados por

${ }^{4}$ As Musas são entidades genuinamente gregas, sem correspondência no oriente. Cf. M. L. West, The East face of Helicon: West Asiatic Elements in Greek Poetry and Myth (Oxford, Clarendon Press 1997) 172.

${ }^{5}$ J. L. Brandão, Antiga Musa: arqueologia da ficção (Belo Horizonte, Faculdade de Letras da UFMG 2005) 33.

${ }^{6}$ Op. Cit, 35.

${ }^{7}$ Op. Cit, 36.

${ }^{8}$ Cf. P. E. Easterling, B. M. W. Knox, Historia de la Literatura Clásica (Madrid, Editorial Gredos 1990) 67.

${ }^{9}$ Sobre essa questão, Aristóteles (Po.1456b) afirma que saber "o que é uma ordem ou uma súplica, uma explicação, uma ameaça, uma pergunta, uma resposta, e outras que tais" é função do ator ou do profissional dessa arte. Logo, o que importa é a total liberdade criativa que o poeta possui.

${ }^{10}$ Brandão, 2005, p. 36. 
parte do poeta. ${ }^{11}$ Nos versos que antecedem o 'Catálogo das naus', por exemplo, o poeta se coloca frente à Musa para pedir que narre os nomes dos comandantes e reis gregos que empreenderam a viagem a Tróia: ${ }^{2}$ "Dize-me agora, ó Musa que no Olimpo tendes vossas moradas - pois sois Deusas, estais presentes e todas as coisas sabeis, ao passo que a nós chega apenas a fama e nada sabemos" (cf. 2. 484485). É possível, então, definir como um dos papéis centrais da Musa nos poemas homéricos (e também na obra de Hesíodo) ${ }^{13}$ a capacidade de lembrar ao poeta fatos relevantes do passado, que o inevitável transcorrer do tempo pode levar ao esquecimento. Ressalte-se, também, que "ao exporem o poeta, esses poemas consagram nada menos que o refinado conjunto de relações entre verdade(s) e psê̂dos a que depois (desde os Romanos) se chamou ficção. O que poderia também ser o outro nome da Musa". ${ }^{14}$ A ela é atribuído o papel de entretecer, enredar, embaraçar os múltiplos fios que compõem a história narrada.

Todo o texto épico enfatiza os valores guerreiros, ou da aristeía, ${ }^{15}$ de heróis gregos ou troianos, na medida em que são esses indivíduos quem protagonizam as mais relevantes contendas, sempre buscando a areté (excelência), timé (honra dada por mérito) e kléos (glória, fama), mesmo que para isso seja necessário morrer no campo de batalha. Os combates dos grandes exércitos acabam por realçar ainda mais o desempenho extraordinário de alguns heróis, embora estes sejam igualmente importantes para a descrição do comportamento militar. Assim, o termo aristeía serve para assinalar um momento especial de bravura de um guerreiro, que pode terminar ou não com a vitória de um combatente sobre o outro, já que, como afirmam Easterling

${ }^{11}$ Cf. M. H. Rocha Pereira, Estudos de História da Cultura Clássica (Lisboa, Fundação Calouste Gulbenkian 2006 ${ }^{10}$ ) v. 1, 157.

${ }^{12} \mathrm{O}$ poeta fará, ainda, referência à Musa em outras passagens (cf. Il. 11.218-220, 14.508-510, 16.112-113), porém apenas a menção inicial nos interessa, na medida em que é esse passo do Exórdio que será retomado/transformado por Mário de Carvalho.

${ }^{13}$ Veja-se a análise sobre o papel das Musas em Hesíodo no capítulo Ficções e As Musas ensinam a mentir realizada por J. L. Brandão, Antiga Musa: arqueologia da ficção (Belo Horizonte, Faculdade de Letras da UFMG 2005) 76-90 e 115-143.

${ }^{14}$ Brandão, 2005, 178.

${ }^{15}$ Alguns termos homéricos de valores guerreiros são: áristoi ("os melhores"), aristéia ("bravura"), timé ("honra"), areté ("excelência”), kléos ("glória, fama”). Veja-se Rocha Pereira, 2006, 122-143.

Faculdade de Letras | Universidade de Coimbra 
e Knox, a "Ilíada é nada mais que uma celebração maciça da luta heróica". ${ }^{16}$

Deste modo, em variados episódios se afirmam a coragem e valentia do guerreiro: a aristeía de Diomedes (cf. 5 passim) é enaltecida em todo o canto, pois o herói é movido pela necessidade de outorgar "força e coragem, para que se tornasse preeminente entre todos os Argivos e obtivesse uma fama gloriosa" (5.1-3). O combate entre Heitor e Ájax também assegura a celebração dos valores guerreiros, mesmo que desse duelo não saia um vencedor: quando o troiano desafia os Gregos para a luta, prevê que no futuro, mesmo morto, sua glória jamais perecerá (7.66-90); também Ájax, escolhido por sorteio para o combate, exulta por imaginar que pode vencer o opositor (7.183-199). ${ }^{17}$ Assim, na Ilíada, os guerreiros que fogem, embora se mantenham vivos, não terão "renome nem vantagem" (5.532), ou seja, serão privados de uma morte honrosa.

Embora o herói da Ilíada busque sempre a consolidação de uma areté, não se pode esquecer que praticamente todas as ações humanas são guiadas pela vontade de um deus, porque "às acções importantes assiste uma dupla motivação, humana e divina". ${ }^{18} \mathrm{O}$ próprio poeta, na proposição do poema, questiona sobre quem teria provocado o conflito entre o Atrida e Aquiles: seria Apolo, que enfurecido pela ofensa feita a Crises, espalhou uma doença terrível de que morriam as hostes (cf. 1. 8-12). A influência divina no desfecho da guerra é tão constante, que os próprios deuses entram no combate (cf. 20 sqq.) com uma parte do panteão ao lado dos Aqueus e a outra dos Troianos. Sob disfarce ou numa simples aparição, os deuses dialogam com os guerreiros, impulsionam-nos ao combate ou retêm-nos, lembram-lhes os princípios por que se norteia a valentia, aliam-se-lhes nos gestos e nos golpes. Por isso, lembra Rocha Pereira, ${ }^{19}$ o canto XX foi chamado de Theomachía na Antigüidade.

Determinantes também para a compreensão da descrição militar e para a análise dos aspectos que marcam a guerra de Tróia são os

${ }^{16}$ Easterling, Knox, 1990, 74.

${ }^{17} \mathrm{Cf}$. ainda outros episódios de aristeia: de Agamémnon, no canto XI; no canto XVII, de Menelau; no XVI, conhecido como 'Patrocleia', a areté de Pátroclo, morto por Heitor.

${ }^{18}$ Veja-se A concepção da Divindade nos Poemas Homéricos in Rocha Pereira, 2006, 116.

${ }^{19}$ Ibidem, 2006, p. 114. 
epítetos caracterizadores de cada herói - genealogia, riqueza, educação, capacidades físicas e intelectuais e os valores que representa -, pois segundo Perelman, uma definição que "parece neutra mostra o que tem de tendencioso quando se lhe pode opor uma descrição diferente cujo carácter seletivo é marcado pelo uso do epíteto, de uma qualidade que se escolhe para pôr em evidência". ${ }^{20} \mathrm{O}$ epíteto pode definir com maior exatidão um substantivo; pode funcionar como atributo e como nome predicativo do sujeito. Tal relação semântica entre o adjetivo e o nome pode ter um valor enunciativo que extrapola a acepção própria do nome ou manifestar um significado que lhe é intrínseco. ${ }^{21}$ No que diz respeito ao aspecto formal, Parry ${ }^{22}$ adverte que um epíteto pode ocorrer como um substantivo; ou como um aposto, e não necessariamente ser representado por um adjetivo.

Assim, pode-se definir o epíteto como "uma expressão que se ajunta a um nome servindo para ampliar, quantificar, qualificar, restringir, realçar uma idéia que pode ou não ser-lhe inerente". ${ }^{23}$ Vejamos, por exemplo, o epíteto freqüentemente empregado para caracterizar Penélope: "sensata" (cf. Od. 15.41, 17.36), que enfatiza um atributo já conhecido da personagem; seria diferente se esse epíteto fosse empregado para se referir a Helena, que não é tradicionalmente designada por essa característica, e sim como a "divina entre as mulheres" (cf. Il. 3.171), numa menção a sua beleza.

Mas além da caracterização individualizada dos heróis, o combate homérico é, naturalmente, um fenômeno coletivo, onde o retrato do vigor humano conta. Voltemos a atenção para um aspecto relevante a propósito da estrutura da guerra na Ilíada: a composição dos batalhões e das hostes, além das armas usadas e o tipo de competência - cavalaria ou infantaria, as posições relativas no campo de batalha, a oposição entre adversários, elementos que se realçam no combate. Esses elementos são retomados por Mário de Carvalho de forma sistemática no conto A Inaudita Guerra da Avenida Gago Coutinho (p. 27-35) e no Livro

${ }^{20}$ Cf. C. Perelman, O Império Retórico: Retórica e Argumentação (Porto, Edições Asa 1993) 65.

${ }^{21}$ Cf. H. Lausberg, Elementos de Retórica Literária (Lisboa, Fundação Calouste Gulbenkian 1967²), 155 §206, 193 §309-316.

${ }^{22}$ Cf. M. Parry, L'épithète Traditionnelle dans Homère (Paris, Les Belles Lettres 1928) 24-25, nota 1.

${ }^{23}$ L. L. Silva, Acerca de Héracles ânimo de leão (Belo Horizonte, Faculdade de Letras 2008) 194, 50. (Tese de doutorado apresentada à FALE-UFMG). 
Grande de Tebas. Voltemos à Ilíada. No segundo canto, Zeus envia um sonho nocivo a Agamémnon, que o induz a armar os Aqueus, na crença de que a tomada de Tróia se daria naquele momento (cf. 2.8-15). Após se reunir em assembléia e travar uma longa discussão, o exército aqueu resolve se deslocar em direção ao inimigo troiano, o que possibilita uma descrição dos diversos elementos que compõem um exército na Ilíada.

A própria reunião dos Gregos e dos Troianos em assembléia (cf. Il. $2.51,9.11-15,2.788$ ) é um traço importante para o qual se deve atentar, pois indica um estágio evolutivo digno de registro: a atitude de se reunir em grupo para decidir um assunto revelaria o caráter civilizado de um povo. Esse tipo de reunião é realizada inclusive pelos deuses, à semelhança da que Zeus convocou para exortar as outras divindades a não prestarem auxílio nem aos Troianos nem aos Gregos (8.1-12). ${ }^{24}$

Mas não é só em potência, como cabedal ameaçador na iminência do combate, que o poema homérico caracteriza as hostes em confronto. Delas se apodera o movimento, na hora em que os dois campos efetivamente se confrontam. A estrondosa marcha do exército aqueu é descrita através de "seis símiles sucessivos" 25 que acentuam o brilho intenso do bronze das armas (Il. 2.455-458), o fragor dos cascos de cavalos e pés humanos, a grandeza do exército e da habilidade de seus comandantes. Ajudam a caracterizar o exército em marcha não só os elementos visuais, mas também os sons emitidos pelos guerreiros durante os embates, pois o grito de guerra (ou mesmo o silêncio) pode indicar a disposição para a refrega (cf. 2. 333-334, 395, 780-785). Assim, no primeiro encontro dos dois exércitos que ocorre na Ilíada, "os Troianos levantaram um grito como se fossem pássaros: era como a voz dos grous que ressoa do céu, quando fogem do inverno às desmedidas tempestades e com gritos se lançam no vôo até às correntes do Oceano" (3.2-6); do outro lado da contenda, "os Aqueus avançavam em silêncio, resfolegando força, cada um desejoso de auxiliar o companheiro" (3.8-9). É habitual, no texto épico, que o guerreiro grite, quer seja para amedrontar o inimigo, para incitar os companheiros ao combate

${ }^{24}$ Lembre-se que no Ciclope de Eurípides, os monstros são caracterizados como Bárbaros justamente por não se reunirem em assembléias (cf. Cyc. 119); na Odisseia esse tipo de reunião dirigida por anciãos é uma prática comum (cf. Od. 2. 7-257), que possibilita exposições de idéias e posições diversas, a qual poderíamos denominar como um costume democrático.

${ }^{25}$ Cf. Easterling, Knox, 1990, 69. Cf. esses símiles em Il. 2. 455-483. 
e estimular, em si mesmo, o ânimo, ou como manifestação de triunfo daquele que ganha a contenda (cf. 4.450-72).

O local onde decorre o embate das múltiplas raças é a planície do Escamandro (2.465), porque o alinhamento das hostes numerosas só é possível em uma vasta campina. No entanto, "a marcha é também o pretexto para uma larga revista poética dos contingentes das diferentes regiões da Grécia (...)" ${ }^{26}$ É através de uma 'lista' que se pode distinguir as primeiras posições dos batalhões, os tipos de armas e de batalhas e os sons produzidos pelo exército, embora o confronto não ocorra nesse momento. Para realizar tal descrição, o poeta evoca a Musa, porque segundo ele:

A multidão eu não seria capaz de enumerar ou nomear, nem que tivesse dez línguas, ou então dez bocas, uma voz indefectível e um coração de bronze,

a não ser vós, Musas Olímpicas, filhas de Zeus detentor da Égide, me lembrásseis todos quantos vieram para debaixo de Ílion. (Il. 2.488-492)

Através dessa afirmação, evoca-se a imagem de um exército tão poderoso e numeroso que seria impossível a um ser humano descrevê-lo sem a ajuda divina. No desenho de cada corpo de tropa, o poeta revela quem é seu chefe, que excede seus subordinados em algum aspecto especial, e a procedência de cada grupo. Desta cena do 'catálogo' homérico, já analisada vastamente pela crítica, ${ }^{27}$ citamos, a título de exemplificação, os retratos de alguns chefes e de suas principais qualidades, pois seus traços são importantes para a compreensão do exército em seu conjunto e da configuração da areté de um guerreiro. "Filoctetes, o sapiente archeiro", por exemplo, comandava os guerreiros de Metona e Taumácia (2. 716-718); "o famoso lanceiro Idomeneu" chefiava os Cretenses (2. 645); os Lócrios eram dirigidos pelo "rápido Ájax" (2. 527). Porém, o mais poderoso e nobre comandante grego é Agamémnon, que chefiava cem naus e as mais poderosas e numerosas hostes, "ele próprio vestido na sua glória de bronze viril, destacando-se

${ }^{26}$ Cf. Easterling, Knox, 1990, 69. O termo ‘catálogo das naus' advém, segundo estes autores, de uma antiga lista das naves que se reuniram em Áulide no início da campanha. Veja-se essa descrição na peça de Eurípides, Ifigênia em Áulide.

${ }^{27}$ Cf. M. J. Edwards, 'The structure of Homeric catalogues', TAPhA 110 (1980) 81-105; J. F. Gaertner, 'The Homeric catalogues and their function in epic narrative', Hermes 129 (2001) 298-305. 
no meio de todos os heróis" (2. 575-580). Também o exército troiano é descrito através do 'catálogo', com ênfase nos mesmos aspectos com que o inimigo grego fora apresentado. No entanto, o desenho do contingente troiano é traçado de forma mais sucinta: menciona-se o nome do chefe, a proveniência da tropa e algum outro pormenor, que, entretanto, não possibilita a elaboração de um esboço detalhado do exército troiano e de seus aliados. Antes da listagem dos chefes troianos, Íris alerta Heitor sobre o poderio bélico dos Helenos e o exorta a pedir aos aliados que levem aqueles que estão sob seu comando para a planície de Batieia, para ali separarem as tropas (2.790-815). Dessa separação temos a visão do contingente troiano e de seus aliados. O primeiro a quem o poeta se reporta é Heitor "de elmo faiscante", superior aos subordinados pela alta estatura e pela capacidade de comando, o chefe troiano das melhores hostes que lutavam com lanças (2. 816-818). Os Dardânios eram comandados pelo "valente Eneias", filho de Afrodite e Anquises, ajudado pelos dois filhos de Antenor (Arquéloco e Acamas), "bons conhecedores de todo o combate" (820-823). Os Cícones, exímios lanceiros, eram comandados por Eufemo, "filho de Ceas criado por Zeus" (846-847). Já Sárpedon e o "irrepreensível Glauco" comandavam os Lídios.

Em relação à forma de combate, ambos exércitos são formados tanto por pelotões de infantaria quanto de cavalaria, e usam lanças ${ }^{28} \mathrm{e}$ escudos de proteção. Mas, Lourenço ${ }^{29}$ chama a atenção para o fato de que o poeta é mais explícito em relação à genealogia dos combatentes, "do que na visualização das posições, na linha de combate, de cada herói”. Assim, os guerreiros mais valentes vão à frente; atrás vem a "chusma" ou "turba" de soldados menores, que o poeta não pára para descrever. ${ }^{30}$

A famosa cena da teichoscopía ("Vista da Muralha", Il.3.161-163) produz também uma descrição eficaz do poderoso exército aqueu e de seus comandantes. O rei troiano e outros anciãos encontram-se no alto da muralha que circunda Tróia, quando, ao avistar Helena caminhando, Príamo a convida a observar seus antigos familiares e amigos. Vinda da Hélade, a mulher de Menelau é a figura mais indicada para identificar os atacantes, primeiro pela raça, depois pelo epíteto e pelo nome. A conversa estrutura-se através de um "esquema pergunta-resposta-

\footnotetext{
${ }^{28}$ No canto VII, tanto Heitor com Ájax usam essa arma.

${ }^{29} \mathrm{Cf}$. a Introdução ao poema realizada pelo tradutor F. Lourenço, 2005, 17.

${ }^{30}$ Ibidem, 2005, p. 17.
} 
comentário" 31 que encontra eco no texto euripidiano, como veremos. Primeiramente, Príamo pergunta a Helena quem é aquele "Aqueu tão alto e tão forte" (3.167); o chefe da expedição que tomou Tróia é caracterizado por Helena como "o Atrida, Agamémnon de vasto poder", exímio lanceiro e "rei excelente" (cf. Il. 3.179), atributos adequados para a responsabilidade do comando que assumiu. Nessa cena, embora o rei troiano faça menção à beleza do rei de Micenas, o epíteto escolhido realça o poderio de alguém que, além do fato de deter o comando de várias cidades, conseguiu reunir inúmeros outros comandantes e navios para o ataque aos Troianos. É essa capacidade de comando que se vê destacada no 'catálogo das naus': Agamémnon detinha Micenas, Corinto, Cleonas, Sícion, Hisperésia, Gonoessa, Egíalo e Hélice; “com ele seguiam as melhores e mais numerosas hostes, ele próprio vestido de sua glória de bronze viril, destacando-se no meio de todos os heróis, porque ele era o mais nobre e comandava a hoste mais poderosa" (cf. Il. 2. 569.580).

Seguindo a estrutura de pergunta-resposta, o velho rei indaga Helena sobre aquele que "é mais baixo por uma cabeça que o Atrida Agamémnon, mas é mais largo de ombros e de peito" (3.193-194). A espartana descreve o senhor de Ítaca com o mesmo epíteto que encontramos na Odisseia, o "filho de Laertes, Ulisses de mil ardis, que foi criado na terra de Ítaca" (3.200), "conhecedor de toda a espécie de dolos e planos ardilosos" (3.202). Esse epíteto evoca a capacidade imaginativa do herói para criar soluções "ardilosas" para os problemas encontrados. Se os epítetos de Agamémnon enfatizam sua capacidade nata para comandar, a caracterização de Ulisses como polýmetis ou polyméchanos ('prudente' e 'de mil ardis') ressalta sua astúcia, sensatez e inteligência. ${ }^{32}$ Antenor, um ancião troiano, pelas memórias do passado, evoca a imagem de Ulisses como aquele com o qual nenhum outro mortal podia rivalizar (3. 223). Nessa estruturação do diálogo, o herói inicialmente parece estar em desvantagem em relação a determinado

${ }^{31}$ Cf. C. Gonçalves, 'O motivo épico da teichoscopía: confronto do modelo de Ilíada, 166-242 e de Fenícias, 88-196’, Humanitas LIII (2001) 141-169, 144. A autora realiza um estudo comparado sobre as cenas da teichoscopía na Ilíada e em Fenícias de Eurípides, e afirma que para fugir a uma certa aridez própria dos catálogos, há no texto uma "introdução dos apontamentos sobre o estado anímico dos personagens", 142.

${ }^{32}$ Menelau recebe o epíteto de "dilecto de Ares" (Il. 4.13) ou "excelente em auxílio" (Il. 4.220). Do lado troiano, o herói Heitor é o guerreiro "do elmo faiscante" (Il. 3.83). 
aspecto, mas em seguida é realçado um outro atributo que o torna superior de certa forma, "o que anula a relevância da característica em que o guerreiro fica a perder, sobrepondo-se-lhe e valorizando a imagem definitiva do herói". ${ }^{33}$

De forma mais sucinta e respondendo ao questionamento do ancião, Helena define Ájax como "o baluarte dos Aqueus" (3.229) e Idomeneu como "um deus entre os cretenses". Já a imagem geral dos Aqueus é concentrada no epíteto "de olhos brilhantes". Embora pareça secundário do ponto de vista da adjetivação dos Helenos, esse último epíteto pode ser essencial "para o ritmo do verso, para o colorido de uma imagem, para a representação de um excesso, para a reiteração de uma idéia". ${ }^{34}$

Helena não faz referência a Aquiles, pois ele e os Mirmidões não estavam agrupados junto ao restante do exército desde a querela entre o Pelida e Agamémnon. Porém, é necessário ressaltar os epítetos que exaltam sua habilidade física. Ao contrário do que ocorre com o rei de Micenas que tem a beleza e a capacidade de comando realçadas, os principais epítetos de Aquiles, "de pés velozes" (1.58) e "desbaratador de homens" (16.145-146), enfatizam sua agilidade, extraordinária força física e coragem frente aos outros combatentes, porque é "de longe o mais valente dos Aqueus", afirma Ulisses (19.216). É especialmente nos cantos em que trava uma luta sangrenta para se vingar da morte do amigo Pátroclo que sua rapidez, força e bravura são realçadas de forma excepcional (cf. 20, 21, 22).

São estes, no essencial, os contornos por que a épica define o fenômeno bélico, nos seus agentes, motivos plásticos e valores que o regulam.

\section{A 'guerra' no conto de Mário de Carvalho}

A questão central do conto A inaudita guerra da Avenida Gago Coutinho ${ }^{35}$ é o amálgama de duas épocas históricas díspares, provocado por um deslize de Clio, Musa da História, que transporta os personagens para uma outra época e contexto, através de uma dissolução transitória

${ }^{33}$ Gonçalves, 2001, 145.

${ }^{34}$ Lages, 2008, 49.

${ }^{35}$ Este conto de Mário de Carvalho é "uma das obras sugeridas pelo Programa de Língua Portuguesa do Ministério da Educação para uma leitura orientada no $8^{\circ}$ ano unificado". (cf. Couto, 2003, 01) 
da realidade que poderíamos denominar de 'viagem' fantástica pelo tempo. $\mathrm{O}$ evento insólito ${ }^{36}$ que coloca frente a frente dois grupos armados na década de 80 no centro de Lisboa é marcado, já no título, como um acontecimento extraordinário, cuja expressão inicial, "inaudita guerra", assinala duas questões importantes para nossa análise: em primeiro lugar, o acontecimento central do conto, a guerra, temática histórica e literária freqüentemente abordada na obra do autor; em segundo lugar, a qualificação desse confronto armado como "inaudito", termo que significa "de que nunca se ouviu dizer", "de que não há exemplo" ou ainda "extraordinário, maravilhoso ou fantástico". Dentro da coletânea a que pertence, este é também um conto central, que por isso mesmo lhe dá o título; a ele está, de fato, subjacente uma teorização sobre o que seja produzir uma narrativa ficcional.

A associação de um tema histórico (a guerra) ao termo "inaudita" possibilita a instauração do insólito ou fantástico em meio a rotina lusitana. Há como que um regresso ao mais antigo sentido de 'história', o que presidiu à instauração do gênero por Heródoto, para quem ficção e narrativa histórica se harmonizam como duas faces da mesma moeda, abrindo-se, pela sua articulação, um espaço a questões culturais, do âmbito da antropologia, dentro do relato histórico em sentido restrito.

Ao contrário da informação paradoxal a respeito do evento narrado, uma guerra da qual nunca se ouviu contar ou fantástica, a delimitação espacial do encontro entre os dois exércitos é exata: a Avenida Gago Coutinho, situada na região central de Lisboa. Esse nome já sugere algumas reflexões sobre o texto, pois Gago Coutinho, figura histórica importante, foi considerado como "o Grande Almirante das Estrelas do Sul', que empreendeu um feito igualmente inaudito (...) extraordinário e inacreditável: a primeira travessia aérea do Atlântico Sul, em 1922, com Sacadura Cabral". ${ }^{37}$ A eleição de um espaço notório, pela evocação que suscita de um evento histórico, parece reafirmar o caráter fantástico ("inaudito") dos fatos que ali irão ocorrer no plano da ficção. É como se a realidade histórica de algum modo rivalizasse com os contornos formidáveis da fantasia.

${ }^{36}$ Cf. o conceito de insólito em A. M. S. Batista, 'Reflexões acerca do gênero literário na narrativa curta de Mário de Carvalho', ABRAILC 2007: Literaturas, Artes, Saberes (São Paulo 2007) 01.

${ }^{37}$ R. M. S. Couto, "Subsídios para uma leitura orientada do conto A inaudita guerra da Avenida Gago Coutinho de Mário de Carvalho", Máthesis 12 (2003) 313-325, sobretudo 315 . 
A explicação dada pelo narrador para os estranhos acontecimentos que tomam o centro de Lisboa é assinalada logo no início do texto: "O grande Homero às vezes dormitava, garante Horácio". ${ }^{38}$ Outros poetas dão-se a uma sesta, de vez em quando, com prejuízo da toada e da eloquiência do discurso. Mas, infelizmente, não são apenas os poetas que se deixam dormitar. Os deuses também". ${ }^{39}$ Partindo da afirmativa horaciana de que até os grandes poetas erram, sobretudo os épicos, graças à extensão dos assuntos com que lidam - uma ironia se tida em consideração a brevidade do conto, a que se pretende conferir traços de 'narrativa épica' -, a sucessão dos estranhos eventos que tomam a capital do país é anunciada como uma falha divina. Ao unir a esfera dos deuses à humana, a narrativa indica o anacronismo de datas que se sobrepõem, para possibilitar o tom fantástico do enredo. Dessa forma, o mesmo deslize cometido por Homero será perpetrado por Clio, ${ }^{40}$ esclarece o narrador:

Assim aconteceu uma vez a Clio, musa da História que, enfadada da imensa tapeçaria milenária a seu cargo, repleta de cores cinzentas e coberta de desenhos redundantes e monótonos, ${ }^{41}$ deixou descair a cabeça loura e adormeceu por instantes, enquanto os dedos, por inércia, continuavam a trama. Logo se enlearam dois fios e no desenho se empolou um nó, destoante da lisura do tecido. Amalgamaram-se então as datas de 4 de Junho de 1148 e de 29 de Setembro de 1984. (Carvalho, 1992, 27)

${ }^{38} \mathrm{O}$ comentário evocado de Horácio consta de Arte Poética, 358-360, na qual o autor afirma: "E não posso deixar de indignar-me todas as vezes que dormita o bom Homero: contudo, é natural que, na descrição de tão grande assunto, alguma vez nos domine o sono".

${ }^{39}$ Carvalho, 1992, 27.

${ }^{40}$ Clio, "a Fama", era a musa da História e a inventora da cítara. Cf. Spalding, T. Dicionário da Mitologia Greco-latina. Belo Horizonte: Itatitaia, 1965, s.u.

${ }^{41} \mathrm{O}$ narrador descreve o relato histórico como uma atividade "monótona" e "redundante", talvez numa alusão às repetidas guerras que assolam a humanidade, com seus tons cinzentos que relembram os desfechos trágicos de muitas delas. A referência às "cores cinzentas" que caracterizam a escrita historiográfica pode ser associada ao tom direto e sem eloqüência que caracteriza tal narrativa, em contraposição às produções ficcionais ou poéticas (cf. 27). Lembre-se que Helena, em Ilíada (3. 125-128), bordava também, num tecido, os acontecimentos em Tróia, cumprindo, no bordado, a função do narrador ou historiador. 
Através dessa introdução, o conto alude aos poemas homéricos, ou mais especificamente, à função da Musa na narrativa épica. Horácio atribui a ela um papel essencial para o desenvolvimento da narrativa ao afirmar que "a Musa deu aos Gregos o talento e a possibilidade de falar com grande elevação, a eles que eram ambiciosos, mas só de alto renome". ${ }^{42}$ Se na Ilíada e na Odisseia, a Musa tinha como função primordial a capacidade de "cantar" os feitos dos grandes heróis ou "lembrar" ao poeta fatos que poderiam ser esquecidos, em A Inaudita Guerra, embora por meio de um erro e com uma 'toada' irônica, é ela também a responsável pela composição (ou transformação) da trama narrativa, que culminará com o encontro de europeus e árabes de épocas diferentes em um mesmo local. Responsável por 'tecer' a narrativa histórica, Clio, considerada a Musa da história e da criatividade, deixase tomar por uma sonolência que transformará o curso histórico dos personagens envolvidos na ação. Por ironia, a Musa, que devia trazer à incapacidade humana o esclarecimento e a memória, vem afinal, ela mesma, por uma cedência ao sono - uma espécie de debilidade física a que os deuses deviam ser imunes -, embaraçar grosseiramente dois momentos históricos. É como se a Musa, incorporada no Autor, viesse confundi-lo, em vez de esclarecê-lo. Ao mesmo tempo, do ponto de vista da tradição literária, a referência à Musa da história deixa de constituir o habitual "apelo ou invocação", para se transformar na justificação de uma história ficcional.

O ano que se cruza com Setembro de 1984 é 1148 d. C., o que nos remete a um evento histórico importante que marca o nascimento de Portugal como nação independente. A atual Lisboa, chamada pelos árabes de al-Lixbûnâ, foi invadida pelos mouros da África do Norte no século VIII d. C. A reconquista ocorreu em 1147, quando a segunda Cruzada, com contingentes flamengos e ingleses, ajudou Afonso Henriques na conquista da região. ${ }^{43} \mathrm{Ou}$ seja, em 1148 d. C., um ano após a reconquista, os árabes, no conto de Mário de Carvalho, tentam cercar e tomar novamente Lisboa (IG. cf. 28).

Não é sem motivo que em uma manhã de Setembro, os automobilistas que passavam pela Avenida Gago Coutinho levaram um grande susto com a inusitada invasão com que se deparavam: um exército composto por mais de dez mil árabes, azenegues e berberes (IG. 28)

${ }^{42}$ Cf. Horácio, Arte Poética, 323-324.

${ }^{43}$ Cf. Ramos, M., Ribeiro, A., Peres, D. História de Portugal. Porto: Portucalense Editora, 1928-35, v. 2, p. 50-51.

Faculdade de Letras | Universidade de Coimbra 
aparece em meio ao trânsito de Lisboa. Essa inesperada situação coloca frente a frente duas culturas completamente diferentes e traz a tona um tema freqüente no autor, o encontro com o 'outro', que nesse conto não é reconhecido pelos Portugueses modernos como seu 'igual', mesmo fazendo parte da constituição do povo lusitano. No conto português, o anacronismo, que cria a hostilidade, é apenas uma máscara sob a qual se esconde um verdadeiro e profundo parentesco. Porque o que se realça em A inaudita guerra da Avenida Gago Coutinho é o reencontro de povos hoje distintos, mas que fazem parte da composição da cultura portuguesa (que é também árabe), na medida em que Portugal, antes de se constituir como nação, era um território tomado por uma combinação de povos e de civilizações diferentes. ${ }^{44}$

À semelhança da tradição narrativa épica sobre a guerra, o espanto que toma os automobilistas é marcado, inicialmente, pelos sons provocados pelo surgimento inesperado de um exército árabe, proveniente da Idade Média, em pleno centro de Lisboa, numa manhã que aparentemente seria rotineira. Dessa forma, "por instantes, foi, em toda aquela área, um estridente rumor de motores desmultiplicados, travões aplicados a fundo, e uma sarabanda de buzina ensurdecedora" (IG. 27). Não são os corações humanos que se alteram com o susto; são as máquinas que, sob o comando do Homem, parecem reagir, numa transferência curiosa do humano para o técnico. "Tudo isto de mistura com retinir de metais, relinchos de cavalos e imprecações guturais em alta gritaria" (IG. 28), que caracterizam o avanço misterioso de um estranho inimigo; são esses ruídos o primeiro indício de uma dissipação da rotina (ou do real) e do estabelecimento de um evento "inaudito", insólito, que marca o texto. A tropa de Ibn-el-Muftar, que tentava cercar Lixbuna, antigo nome do território de Lisboa, assusta-se não só pelo ruído fragoroso que substitui "o suave pipilar dos pássaros e o doce

${ }^{44}$ Veja-se a entrevista de Mário de Carvalho concedida a J. Paulo Cotrim, J. P. Alguma coisa me perturba. Ler Livros e Leitores 34, (1996) 38-49, 44. A propósito do conto, o autor afirma que "nós somos uma nação muito antiga. E antes de sermos nação, isto tinha sido um caldeamento muito grande de povos e civilizações. Por detrás de nós, há toda uma estrutura histórica. Quando eu escrevo A inaudita guerra da Avenida Gago Coutinho, quando os mouros aparecem aí num engarrafamento em Lisboa, é isso que eu quero dizer: atenção, nós somos uns e somos outros. Ou seja, temos cá uma civilização árabe também".

Faculdade de Letras | Universidade de Coimbra 
zunido dos moscardos" da região que atravessava ${ }^{45}$ (IG. 28), mas, também, pela visão faiscante ${ }^{46}$ proporcionada pelos carros coloridos e as imensas paredes "cobertas de janelas brilhantes" (IG. 28), natureza e civilização aliando-se para apavorar o invasor, que o anacronismo também afeta. Observe-se que o termo "mistura" tem a função de designar tanto a ocorrência dessa situação insólita quanto a constituição do povo português, que se formou através da junção de múltiplos povos e culturas.

Da mesma forma que na caracterização do herói épico, os personagens centrais, representantes dos grupos armados, são definidos por epítetos; os que exprimem categoria profissional: o almóada Ibnel-Muftar (IG. 28), o agente de segunda classe da PSP Manuel Reis (neste caso muito irônico pela modéstia da patente, $I G$. 29, 35), o comissário Nunes (IG. 31, 32, 35), o capitão Aurélio (IG. 32), o capitão Soares (IG. 33, 34, 35), o coronel Vaz Rolão (IG. 35); ou qualidades de caráter: Ali-ben-Yussuf, homem piedoso e temente a Deus (IG. 28), os briosos homens da Polícia de Intervenção (IG. 32); ou a raça: o beduíno Manuel Beshewer (IG. 31). São também caracterizadores os nomes, ${ }^{47}$ que soam estranhos aos ouvidos modernos, mas que são expressivos de um coletivo desconhecido, a que todos eles pertencem, além das suas ações em campo de batalha. Dotado de uma capacidade de liderança e dinamismo próprio de um estrategista experiente, Ibn-el-Muftar, ao contrário de seu tenente que queria prostrar-se para orar, percebendo rapidamente "que a situação requeria antes soluções práticas e muito tacto (...) ordenou que ninguém se mexesse" (IG. 28). Há que notar, de novo, o choque irônico da narrativa: se ao chefe, dinâmico, a imobilidade da oração parece inoportuna quando a situação exige soluções práticas e imediatas, a que ele responde com o gesto enérgico de erguer o pendão e gritar uma ordem, afinal o que lhe sai da boca é uma inesperada ordem

${ }^{45}$ Observe-se que Mário de Carvalho recorre a uma estratégia literária específica para exprimir o contraste entre dois momentos históricos e civilizacionais distintos: a oposição dos sons suaves de um ambiente campesino a que os árabes estavam acostumados e o barulho ensurdecedor do trânsito lisboeta; além das cores excessivas e brilhantes, que assustam os homens de El-Muftar (cf. 27-28).

${ }^{46} \mathrm{Cf}$. em $\mathrm{Il}$. 2.455-458, como a imagem do exército associa-se ao brilho do bronze das armas.

${ }^{47} \mathrm{Cf}$. Couto, 2003, nota 15 . "O elemento "Ibn" pode surgir com as variantes "ben" e "aben" e significa "filho de". É usado sobretudo nos nomes de pessoas para indicar filiação". 
de imobilidade, "que ninguém se mexesse!" (IG. 28). Parece ficar, da contradição entre palavra e ação, a idéia de um personagem, que conhece as regras e os padrões da aristeía, mas que age ao avesso. A atitude deste chefe, ao contrário do padrão do guerreiro épico que reage sem hesitação, El-Muftar revela em cada gesto (cofiar a barba, dar um jeito ao turbante) e nas interrogações com que se debate (IG. 28-29) uma verdadeira inoperância. O chefe árabe pensava, com ar perspicaz, sobre a origem do pandemônio a sua volta: “_ Teriam tombado todos no inferno corânico? Teriam feito algum agravo a Alá? Seriam antes vítimas de um passe da feitiçaria cristã? Ou tratar-se-ia de uma partida de jinns ${ }^{48}$ encabriolados?" (IG. 29).

Enquanto isso, numa reação simétrica, Manuel Reis Tobias, agente de segunda classe da PSP em serviço naquela região, do mesmo modo ponderava que aquele tumulto não estava correto e que devia tomar providências (IG.29). Ao contrário do árabe - pelo menos na aparência e dos guerreiros da épica, o policial português não encarnava a figura do chefe enérgico, persistente e decidido; em correspondência com o que a opinião pública portuguesa considera o paradigma da incapacidade da sua polícia - que, em vez de agir para proteger a população em situações de perigo, se esconde na "caça à multa" sobre o cidadão ordeiro e pacífico -, o modesto agente, meio escondido para não ser detectado pelos automobilistas incautos, espiava "no propósito sábio e louvável de surpreender contraventores aos semáforos". A teichoscopía homérica (ou "vista da muralha") (cf. Il. 3.166-242) é substituída por uma observação diferente realizada pelos chefes de ambos os lados: Ibn-el-Muftar observa o tumulto "do alto de seu puro sangue" (IG. 29), enquanto Manuel Reis vê a confusão "meio escondido por detrás das colunas de um prédio" (IG. 29). Tal como o árabe, também ele incapaz de tomar uma atitude frente a tão grandioso exército, avisou o posto de comando sobre a ocorrência (IG. 29). Constatando-se que não havia nenhum evento programado, a "máquina policial" é colocada em ação: é nesse momento que os esquadrões árabes e os pelotões da Polícia de Intervenção se vêem frente a frente. Aos automobilistas, parados no trânsito pelo encontro dos dois exércitos, restava observar a confusão que ora divertia ora irritava: para a maioria, a cena representava "algum reclame" ou a gravação de "um filme" (IG. 30). Assim o quadro

${ }^{48}$ Cf. Couto, 2003, nota 16. "Jinns, na mitologia maometana, são espíritos de categoria inferior aos anjos, com poder sobrenatural sobre os homens e capazes de assumir forma humana ou animal". 
histórico, no seu anacronismo, desperta nos que a ele assistem a noção de que só a ficção o pode explicar.

Como na Ilíada (cf. 2.484 sq.), o conto refere-se às duas frentes inimigas e descreve as características dos exércitos. Em substituição do que poderia ser, na tradição literária grega da épica, o relato de um mensageiro, Mário de Carvalho opta por uma mensagem, emitida "pelo intercomunicador da mota" (IG. 29), do agente de serviço a alertar o comando. ${ }^{49}$ A primeira descrição, portanto, é a da cavalaria moura: montados em possantes cavalos (IG. 29), os beduínos usavam túnicas, turbantes sobre a cabeça (IG.28), além de portarem bandeiras; segundo o policial da PSP, pareciam usar "trajes de carnaval" (IG.29). A referência às armas (IG. 29) completa uma espécie de catálogo, como aquele a que a épica nos habituou na iminência do combate. Com a mesma ironia que perpassa todo o conto, a reação inimiga passou por uma longa cadeia burocrática (IG. 29-30) até se desencadear com aparato. A Polícia de Intervenção veio em carros com sirenes e "pisca-piscas multicores" para transportar os homens que compõem a infantaria, protegida por escudos e viseiras (IG. 32). As armas utilizadas pelos mouros são os $\operatorname{arcos}(I G .31)$, "armas brancas e outros objectos contundentes, cortantes e perfurantes" (IG. 29); as da Polícia portuguesa eram armas de fogo (IG.33). Os "batalhões" portugueses contavam ainda com o contingente da tropa do Ralis e da Escola Prática de Administração Militar, embora os blindados do Ralis não conseguissem avançar pelo engarrafamento medonho que tomava a vizinhança (IG. 32-33). Tais diferenças de vestimenta e armas usadas em uma disputa refletem o confronto de nómoi distintos, mas que, contraditoriamente, são próximos, na medida em que possuem traços constituintes de um mesmo povo.

Se na Ilíad $a^{50}$ a tentativa de se impedir o confronto, para que não fosse derramado sangue inocente, ocorre através do duelo entre os guerreiros, em A inaudita guerra, o mouro Ibn-el-Muftar resolve evitar a luta, inicialmente, por considerar que "aquela peonada toda não se

${ }^{49}$ Da mesma forma que havia um estilo próprio para a linguagem do mensageiro, que narrava detalhadamente os eventos ocorridos fora de cena para os outros personagens arredados da ação, há um estilo próprio de uma mensagem telegráfica em $A$ inaudita guerra; pela própria concisão do conto, é necessária uma brevidade nas descrições (cf. 29). Assim, a descrição do policial indica apenas as informações fundamentais para a tomada de uma decisão, num registro com um tom burocrático.

${ }^{50}$ Também na Ilíada há a mesma tentativa de se evitar o confronto através do duelo entre Menelau e Páris (cf. 3.59-117, 320-380). 
afigurava particularmente ameaçadora" (IG. 30) e, por pensar que se aquilo fosse uma encantação, que o melhor era esperar que passasse (IG. 30); ou seja, o adiamento resulta agora da depreciação de um adversário que se desconhece e que não se compreende. ${ }^{51}$ Dessa forma, optou apenas por fazer uma manobra cautelosa no pequeno espaço que dispunha: "fez que um ou dois esquadrões formassem, com dificuldade, no parque de estacionamento do Areeiro, e uma falange de gente de pé se arrumasse no terreiro da estação de serviço do lado contrário, enquanto o grosso da tropa ocupava a placa central relvada" (IG.30). Impossibilitado de ocupar uma ampla planície para a formação dos esquadrões como as que vemos na Ilíada (cf. 2. 465), sobra ao mouro a possibilidade de alinhar as hostes em locais urbanos e planos, como um estacionamento ou jardim, num claro redimensionamento da noção de espaço. Ironicamente, os lugares que constituem o cenário de um vulgar quotidiano citadino "entram para a história", transformados em campo de estranha batalha. ${ }^{52}$

Entretanto essa tentativa de evitar um confronto não logrou êxito, pois um motorista de caminhão, Manuel da Silva Lopes, irritado, lança uma pedra que acerta no escudo de Mamud Beshewer. Na Ilíada, o início da contenda ocorre da mesma forma: os exércitos estão quietos, quando incitado por Atena, o herói troiano Pândaro dispara uma flecha contra Menelau (cf. 4. 105-130). Em Mário de Carvalho, é um desconhecido que alveja o mais distraído e "dos mais quietos da tropa" (IG. 31), como se houvesse uma espécie de intervenção da mão do destino. Vejamos como ocorre o início da luta:

Desprezivamente, Ibn-el-Muftar deu uma ordem e logo vinte archeiros enristaram os arcos, apontaram aos céus, e expediram, com zunido tenso, uma saraivada de setas, que obrigou toda a gente a meter-se nos automóveis e a procurar refúgio nas portadas dos prédios ou atrás dos camiões. Veio do Areeiro um grande apupo, desta vez convicto, em uníssono. (Carvalho, 1992, 31)

O som da trombeta que indica o início do confronto no texto épico é substituído pelo apupo dos automobilistas assustados. É esse

${ }^{51}$ Veja-se a interessante exploração literária desta incompreensão, demonstrada pela surpresa dos mouros diante dos carros e dos vidros (cf. 30).

${ }^{52}$ Nesse sentido, o jardim escolhido para a manobra do Areeiro é um espaço impróprio para um alinhamento militar, sobretudo porque as hostes estragam as dálias e as hortênsias que embelezam e dão um tom ameno ao local (cf. 32). 
estrondoso ruído que o comissário Nunes recém chegado à Alameda D. Afonso Henriques ${ }^{53}$ ouve e interpreta mal; pensa o policial que os mouros estavam desafiando a polícia. Por isso decide agir: "Toca a varrer isto tudo até ao Areeiro" (IG.31), ordena. O contra-ataque português é também assinalado por um som, agora de um apito, que "pôs a equipa em acção, à bastonada, a eito, por aqui e por além" (IG. 31). Assim repelida uma parcela da multidão para outro local, o policial Nunes reagrupa os homens na praça do Areeiro (IG. 32), numa manobra de recurso após a primeira fase do embate. Já irritado com a confusão em sua volta e vendo os militares portugueses formados em pelotões, ${ }^{54} \mathrm{o}$ chefe mouro "pensou que era, enfim, a guarda avançada de Ibn-Arrik, ${ }^{55}$ o cão tomador de Lixbuna, que vinha aí travar-lhe o passo, a coberto de um encantamento mágico" (IG. 32). Tudo não passa, nesta batalha, de uma engraçada sequiência de equívocos.

$\mathrm{O}$ grito de guerra que caracteriza o avanço do exército troiano na Ilíada como uma espécie de estímulo à contenda (cf. 3.1-5) marcará, igualmente, o ataque dos berberes aos soldados comandados pelo comissário Nunes e aos cidadãos atônitos, aprisionados no engarrafamento de trânsito. Em direção ao inimigo, "num ápice, rompeu uma carga de cavaleiros berberes, aos gritos de guerra, de alfange em riste, ladeando automóveis, amolgando capots" (IG. 32). Do lado português, os "berros enérgicos" do capitão Aurélio servirão apenas para afastar os civis que estão em meio à confusão (IG. 33).

Outra possível influência homérica que destacamos no texto português é o vigor que caracteriza as hostes mouras, qualidade ameaçadora na proximidade da refrega; e também os movimentos que tomam os esquadrões de ambos os lados no momento em que os grupos armados se enfrentam de fato (cf. Il. 2.455-458). Os verbos "romper", "ladear", "amolgar" e "aproximar-se" (IG. 32) propiciam uma imagem do corajoso exército comandado por Ibn-el-Muftar em

${ }^{53}$ Note-se a ironia do nome da Avenida neste contexto, em que a campanha lembra as que acompanharam as da fundação da nacionalidade portuguesa, ao tempo de Afonso Henriques; como também (cf. p. 31) a referência ao Bairro dos Actores, onde se refugia a multidão em fuga, que são os figurantes no espetáculo que este episódio constitui.

${ }^{54}$ É curiosa a leitura que diferentes épocas fazem de iguais realidades ou objetos; "peões de escudo e viseira" são, além de guerreiros medievais, a imagem da moderna polícia de choque (cf. 32).

${ }^{55}$ Ibn-Arrik seria Afonso Henriques. 
movimentação. As tropas portuguesas são, do mesmo modo, descritas por verbos que indicam uma reação covarde de fuga, como "oscilar", "rodopiar", "desfazer", "correr" e "refugiar-se" (IG. 32); fica clara a sua incapacidade de resistência, já que os policiais "não se sentiam preparados para enfrentar cargas de cavalaria moura" (IG. 32). Assim, a busca pela aristeía (valores guerreiros) e a areté (excelência), tal como o herói épico almeja, só se aplica aos invasores árabes, que possuem uma longa tradição em combates, guerras e conquistas. Para o homem contemporâneo, que o português aqui simboliza, salvar a própria vida é mais importante que demonstrar coragem frente ao desconhecido e ao perigo, escudado atrás do balcão da Cervejaria Munique, como uma barricada à medida das práticas de um cidadão anônimo dos nossos dias. São assim "os heróis" de uma moderna sociedade ocidental; perante os grandes momentos da "história", limitam-se a "ver passar, acuados na Munique, árabes a cavalo, de ar ameaçador e façanhudo" (IG. 32), com o coração apertado de susto.

É o capitão Aurélio Soares e a companhia de intendentes que comandava que chega para tentar sanar o problema: vinha com ordens para "proceder a um reconhecimento, avaliar a situação e agir em conformidade, mas sempre com moderação" (IG. 33). Apanhado na refrega, o "herói" ou "chefe", de que o capitão Aurélio veste a pele por força de um estatuto profissional, pensa apenas no perigo que pessoalmente corre, como se "estas coisas só lhe acontecessem a ele!" (IG. 33). Dos seus homens ou das vítimas que lhe competia dirigir ou defender, o pobre "herói" parecia até esquecido, postura que o separa de qualquer verdadeiro ánax homérico.

Ao perceber a chegada dos portugueses que acenavam um trapo branco, símbolo de tréguas saído à pressa da generosidade oportuna de um qualquer locatário da vizinhança (IG. 33), Ibn-el-Muftar, "por instinto", intuiu que os homens eram militares e não pareciam suspeitos (IG. 34); "assim dispôs-se desde logo a parlamentar" (IG. 34), abrindo caminho a um expediente usado pelo herói épico, o envio de embaixadas e as discussões em assembléias, que eram comuns, em Homero, tanto entre os Gregos quanto entre os Troianos. ${ }^{56}$

Quando Ibn-el-Muftar e o policial Aurélio Soares se cumprimentam, encontrando no árabe - língua para um materna, e que o outro tinha aprendido - um instrumento de aproximação, e a trégua se vê, auspiciosa, no horizonte, Clio acordou e percebeu a falha cometida

${ }^{56}$ Cf. Il. 2.51, 2.788, 7. 414, 9.11-15, 9. 165 sq. 
(IG. 34). Deste modo, a Musa, "num credo, desfez a troca de fios e reconduziu cada personagem a seu tempo próprio. De maneira que (...) assim se sumiram os árabes da Avenida Gago Coutinho, deixando o capitão Soares e todos os outros a coçar a cabeça abismados" (IG. 34). O comandante árabe, quando se viu longe de toda a confusão, resolveu não atacar mais Lisboa, pois considerava aquelas aparições sinal de má sorte. A Musa, sem poderes para anular os eventos, resolveu "obnubilar a memória dos homens com borrifos de água do rio Letes", a água do esquecimento (IG. 35); por isso, todos os envolvidos na confusão, em poucos segundos, esqueceram-se do ocorrido. Tal como acontece na Ilíada (cf. 1.8-12, 20 passim), em A inaudita guerra a responsabilidade pelo conflito que quase levou árabes e portugueses a uma outra guerra é da deusa que dormiu durante seu trabalho; afinal também ela a criadora, em sobreposição com o Autor, de um episódio de mágica fantasia.

Não há vencedores nesse conflito: para Ibn-Muftar o acontecimento não provocou nenhum dano, ao contrário, possibilitou-lhe arruinar "campos de Chantarim, nas margens do Tejo, com grande vantagem de troféus e espólios" (IG. 35). Os polícias portugueses tiveram que explicar em juízo porque estavam com seus pelotões em pleno centro da cidade, ato que alguns julgavam como insurreição (IG. 35). Já "Clio, foi privada de ambrósia por quatrocentos anos o que, convenhamos, não é seguramente castigo dissuasor de novas distracções" (IG. 35). Em um conto narrado na terceira pessoa, não deixa de ser curioso que o texto termine com a expressão "convenhamos", com a sugestão de uma relação de cumplicidade entre narrador e leitor. É essa cumplicidade que permite ao leitor entender uma possível promessa de que outras histórias desse tipo (insólitas) seriam contadas no futuro, na medida em que o castigo imputado a Musa não seria suficiente para impedir novos deslizes; afinal de contas, como diria Horácio ${ }^{57}$, "há (...) defeitos para os quais exigimos indulgência”.

\footnotetext{
${ }^{57}$ Arte Poética, 346-347.
} 


\section{Bibliografia}

F. R. Adrados, 'La estructura formal de las tragédias tebanas', Humanitas XLVII (1995) 152-163.

M. S. Alves, Eurípides. As Fenícias (Coimbra, Instituto de Alta Cultura 1975).

T. R. Assunção, 'Nota crítica à bela morte vernantiana', Classica v. 7/8 (1994-1995) 53-62.

A. M. S. Batista, 'Reflexões acerca do gênero literário na narrativa curta de Mário de Carvalho', ABRAILC 2007: Literaturas, Artes, Saberes (São Paulo 2007).

J. L. Brandão, Antiga Musa: arqueologia da ficção (Belo Horizonte, Faculdade de Letras da UFMG 2005).

H. D. Cameron, Studies on the Seven against Thebes of Aeschylus (Mouton 1971).

M. Carvalho, A inaudita guerra da Avenida Gago Coutinho e outras histórias (Lisboa, Editorial Caminho) $1992^{9}$.

M. Carvalho, 'Alguma coisa me perturba', Ler Livros e Leitores 34 (Lisboa, Círculo de Leitores 1996) 38-49. Entrevista de João Paulo Cotrim.

J. A. Clota, Esquilo. Tragedias completas (Madrid, Ed. Catedra/ Letras Universales 1996).

R. M. S. Couto, "Subsídios para uma leitura orientada do conto $A$ inaudita guerra da Avenida Gago Coutinho de Mário de Carvalho", Máthesis 12 (2003) 313-325.

P. E. Easterling; B. M. W. Knox, Historia de la Literatura Clásica (Madrid, Editorial Gredos 1990).

R. M. R. Fernandes, Horácio. Arte Poética (Lisboa, Clássica Editora 1975).

M. Finkelberg, 'A creative oral poet and the Muse', AJPh 111. 3 (1990) 293-303.

C. Gonçalves, 'O motivo épico da teichoscopia: confronto do modelo de Ilíada, 166-242 e de Fenícias, 88-196', Humanitas LIII (2001) 141-169.

J. Hart, Herodotus and Greek History (New York, St. Martin's Press 1982).

H. R Immerwahr, Form and thought in Herodotus (Califórnia, The University of North Carolina 1966).

W.W. Jaeger, Paideia: los ideales de la cultura griega (México, Fondo de Cultura Econômica 1942). 
H. Lausberg, Elementos de Retórica Literária (Lisboa, Fundação Calouste Gulbenkian 19674).

F. Lourenço, Homero. Ilíada (Lisboa, Livros Cotovia 2005).

P. Mazon, Eschyle. Tome I (Paris, Les Belles Lettres 1949).

M. W. Minton, 'Homer's invocations of the Muses: traditional patterns', TAPhA 91 (1960) 292-309.

M. Parry, L'épithète traditionnelle dans Homère (Paris, Les Belles Lettres 1928).

V. Pedrick, 'The Muse corrects: the opening of the Odyssey', YClS 29 (1992) 39-62.

C. Perelman, O Império Retórico: Retórica e Argumentação (Porto, Edições Asa 1993).

M. Ramos; A. Ribeiro; D. Peres, História de Portugal (Porto, Portucalense Editora 1928-35).

M. H. Rocha Pereira, Estudos de História da Cultura Clássica (Lisboa, Fundação Calouste Gulbenkian $2006^{10}$ ) v. 1.

J. Romilly, l'Invention de l'histoire politique chez Thucydide (Paris, Éditions Rue D’Ulm 2005).

T. Spalding, Dicionário da Mitologia Greco-latina (Belo Horizonte, Itatiaia 1965)

E. Sousa, Aristóteles. Poética (Lisboa, Fundação Gulbenkian 1986).

L. L. Silva, Acerca de Héracles ânimo de leão (Belo Horizonte, Faculdade de Letras 2008) 194. (Tese de doutorado apresentada à FALE-UFMG).

M. F. S. Silva, Ensaios sobre Eurípides (Lisboa, Edições Cotovia 2005).

W. G. Thalmann, Dramatic art in Aeschylus' Seven against Thebes (New Haven and London 1978).

J. Torrano, Hesíodo. Teogonia: a origem dos deuses (São Paulo, Iluminuras 2003).

M. L. West, The East Face of Helicon: West Asiatic Elements in Greek Poetry and Myth (Oxford, Clarendon Press 1997). 